\title{
CASE STUDY OF LIZZAT CO-OPERATIVE IN INDIA IN RELATION TO WOMEN EMPOWERMENT
}

\author{
Asst.Prof. Neelam Kapoor ${ }^{1 *}$ \\ *17-laxmi nivas near chaman hotel Mayapur kota, rajasthan
}

*Corresponding Author: -

\begin{abstract}
: -
Women are the biggest assets to society. In today scenario, women have full right to live their lives with full confidence and good status. If a woman can handle house, it is not possible for her to handle outside situation. Today's is women era scenario, each year we celebrate international women's day on March 8th with an aim to mark achievements of women with a special status they deserve in society. In present research paper a women empowerment is describe in context to Lizzat Papad women co-operatives. The factors were studied in context to women employment, status, values, and beliefs. The study shows that lizzat papad main goals are to organize women workers for full employment. Here employment means employment whereby workers obtain work security, income security, food security and social security (at least health care, child care and shelter).
\end{abstract}

\section{(c) $(\$)$}




\section{INTRODUCTION}

Shri Mahila Griha Udyog Lijjat Papad, popularly known as Lijjat, is an Indian woman"s cooperative started in the year 1959, with a seed capital of Rs 80. It is cooperative involved in Lijjat was the brain child of seven Gujarati women from Mumbai. The women lived in Lohana Niwas, a group of five buildings in Girgaum. They wanted to start a venture to create a sustainable livelihood using the only skill they had i.e. cooking. The women borrowed Rs 80 from Chhaganlal Karamsi Parekh, a member of the Servants of India Society and a social worker. They took over a loss-making papad making venture by one Laxmidasbhai. and bought the necessary ingredients and the basic infrastructure required manufacturing papads. On 15 March 1959, they gathered on the terrace of their building and started with the production of 4 packets of Papads. They started selling the Papads to a known merchant in Bhuleshwar. From the beginning, the women had decided that they would not approach anyone for donations or helps even if the organization incurred losses. Lijjat, women cooperatives has branches in seventeen Indian states. Lijjat follows its own financial accountability principle. There is no method for running operations in the organization on credit basis. Because of Lijjat's main motive of generating self-employment for women, no machinery is used at the production level, and everything is done manually. Their main objective is not to compromise with quality and use of machinery also decreases the employment opportunities for women.

Lijjat's manufactures several following

\section{PRODUCTS AND DIVISIONS}

Lijjat's manufactures several products, of which the papad is the most famous:

- Papad (Fourteen flavours, including lasan, moog, mirch, Punjabi ${ }^{\mathrm{l}}$ )

- Khakhra

- Appalam

- Masala

- Vadi

- Gehu Atta (Wheat flour)

- Bakery products

- Chapati

- SASA Detergent Powder

- SASA Detergent Cake (Tikia)

- SASA Nilam Detergent Powder

- SASA Liquid Detergent

Lijjat has several divisions and manufacturing units:

- Flour Division (Vashi)

- Masala Division and Quality Control Laboratory (Cotton Green)

- Printing Division (Cotton Green)

- Advertising Division, Bandra

- Khakhra Division, (Buhari, Valod district)

- Chapati Divisions at Wadala, Borivali, Mulund and Kandivali

- Polypropylene set-up (Kashi-Mira Road)

- Vadi factory

\section{CONTRIBUTION TO SOCIAL SERVICE}

On several occasions, the Lijjat member-sisters have undertaken social service activities such as distributing nutritious food for poor children, donating money for conducting community marriage, instituting prize-money for spread of primary education, undertaking blood donation drive, organising health camps, plantation drives and even making donations to Government bodies. In 1999, the Mumbai City felicitated Smt.Rukminiben B.Pawar, Lijjat President, as an outstanding woman in the field of social work.

Lijjat undertook the rehabilitation of Chincholi (Jogan), the earthquake affected village in the Latur district of Maharashtra. The institution provided the finance and supervised the work of construction of fifty-eight houses for the people of the village. Member-sisters donated money from their daily vanai (wage). After the 2001 Gujarat earthquake, all the branches of Lijjat gave a total donation of more than Rs 4.8 million, including Rs 1 million from the central office. Lijjat built forty houses for the rehabilitation of the people of Bhujpur (Bhachau) in Kutch District

\section{RESEARCH METHODOLOGY}

To evaluate the success of women empowerment the two types of data sources are considered.

1. Primary Source

2. Secondary Source

Primary data was collected through a structured closed/ open-ended questionnaire and interviews with members of Lizzat, (Shri Mahila Griha Udyog Lijjat Papad). Secondary data was collected through internet, newspapers, magazines, journals and annual reports. 


\section{REVIEW OF LITERATURE}

After a detailed study and research, women empowerment is not only the development of women but its also leads to development of economy and society as whole. The growth of the Lijjat brings a great revolution for women and their empowerment. The organization has organized various programmes to promote literacy and computer education for member-sisters and their families. The member-sisters used their organization as a medium to promote their and their families' welfare. In the Valod centre they set up an educational and hobby centre for the rural women. Orientation courses in typing, cooking, sewing, knitting and toy making as well as other courses like child welfare, first aid and hygiene were taught.

[1] The first ever pucca (tarred) road in Valod to be built and inaugurated in 1979 was with the help of the Lijjat, Valod branch.

[2] In 1979, Lijjat teamed up with UNICEF to organize a seminar in Mumbai on "Child Care and Mother Welfare", as part of the International Year of the Child celebrations. [

[3] The Lijjat member-sisters also undertaken social service activities.

\section{CONCLUSION}

Women "e empowerment is not a onetime affair but a continuous process. The development of Shri Mahila Griha Udyog Lijjat Papad should be taken in broader framework of women empowerment. The organization efforts design towards the all-round development of each and every section of Indian Women in society, by giving them their due share. Lizzat is responsible for empowering women by the way of promoting self -reliance, self-confident, selfdependent and educating them to realize their fundamental rights. The impetus may be a particular issue arising out of experience, disadvantage or discrimination, or an aspiration to do something to become self-dependent. Lijjat organization has taken a step in this direction in both condition and position of women. Lijjat has made women financially stable to such an extent that after taking their rightful share for their livelihood, they are contributing generously to societal cause. Lijjat as a „Truste is a service organization engage in serving poor and destitute and to empower women for social development. The task is not too difficult to achieve. The honesty and sincerity on the part of those involved is a must. Hence, the women "s empowerment is the need of the hour.

\section{REFERENCES}

[1].Anil Kumar (2010), "Satisfaction of women entrepreneurs in small businesses", Integral Review A Journal of Management", Vol. 3 No. 2, Dec-2010

[2].Arpita Sharma (2011), "Women Empowerment: Milestones and Challenges”, Kurukshetra, Vol. 59, No.11, September 2011, pp.10-15.

[3].Dr A.S. Shiralashetti (2010), "Problems and Prospects of women entrepreneurs in Karnataka state - A Case study of Bijapur District, Integral Review A Journal of Management, Vol. 3 No. 2, Dec-2010

[4].Dr K Someshwer Rao, (2011) Problems of Rural Women Entrepreneurship in India, BJIMR, BIFT ${ }^{\mathrm{ee}}$ Journal of International Management and Research, Jan-Mar, Apr-June 2011, Vol-III, No-I, II

[5].Dr P. Paramashivaiah, Dr. Aravind.S.(2010), "Empowerment an Empirical Analysis", BJIMR, Vol-II, No-III, IV, April-Sep 2010 pp.54-68

[6].GS Batra, Development of Entrepreneurship (2009), Deep \& Deep Publications Pvt Ltd.,New Delhi - 110027 